\title{
Książi dla dzieci i młodzieży o Janie Pawle II Analiza polskiego rynku wydawniczego
}

\section{Wprowadzenie}

W ybór kardynała Karola Wojtyły na Stolicę Piotrową był jednym z najważniejszych wydarzeń w dziejach naszego narodu. Ta bezprecedensowa decyzja watykańskiego konklawe z 16 października 1978 r. miała wymiar nie tylko religijny, ale stanowiła także pewien przełom światopoglądowy w historii Europy i świata. Skromny kardynał z „dalekiego kraju” swój długi, ponad 26-letni pontyfikat wypełnił bogatą treścią teologiczną, kulturową, cywilizacyjną, a nawet polityczną. Czas jego posługi przypadł na okres gwałtownych zmian w Europie - upadku komunizmu, rozwoju terroryzmu, globalizacji, ekspansji nowoczesnych technologii oraz rosnącej ateizacji bogatych społeczeństw ${ }^{1}$. Biografia Karola Wojtyły zawiera wiele elementów dramatycznych, znaczona jest jednak niezwykłą siłą ducha i konsekwencją w dążeniu do osiągnięcia postawionych sobie celów. Dla Polaków postać papieża Jana Pawła II jest szczególnie ważna ze względu na jej związki z trudną XX-wieczną historią nadwiślańskiego kraju. Przy całym nacisku na uniwersalizm papieskiej posługi, w okresie pontyfikatu widoczne były polskie akcenty². Warto zauważyć, że w tym burzliwym dla Polski stuleciu, naznaczonym niewolą i dramatycznymi wojnami, wybór krakowskiego kardynała na papieża to jeden

1 B. Lecomte, Pasterz, Kraków 2006, s. 7.

2 G. Weigel, Świadek nadziei, Kraków 2000, s. 5-10. 
z nielicznych faktów pozytywnych. Od samego początku szczególne relacje łączyły go z ludźmi młodymi. Były one zauważalne zarówno w kazaniach wygłaszanych do młodego pokolenia, luźnych „pogadankach”, m.in. ze słynnego krakowskiego okna, jak i w świadectwach bezpośredniego z nim kontaktu. Szczerość i bliskość, niekonwencjonalność zachowań oraz młodzieńcza żywotność stanowiły charakterystyczne rysy papieża Polaka. Nic więc dziwnego, że był on postacią budzącą zainteresowanie młodych ludzi, umiejącą rozmawiać z nimi nie tylko o rzeczach codziennych i błahych, ale też o ważnych problemach życiowych. Wymiar tej akceptacji mieści się w spontanicznym określeniu „pokolenie JP II”3. W biografii Karola Wojtyły istnieje zatem wiele różnorodnych aspektów czyniących ją atrakcyjnym tematem książek przeznaczonych dla dzieci i młodzieży. Niewątpliwie ma ona wymiar dydaktyczny, obecne są w niej elementy patriotyczne i uniwersalne wzorce ideowe, a nawet wątki humorystyczne i sensacyjne. Tak więc zasadne wydaje się postawienie pytania o obecność na polskim rynku wydawniczym książek przeznaczonych dla dzieci i młodzieży, które przedstawiają postać Jana Pawła II.

Z przeprowadzonych badań wyłączono adresowane do dzieci i młodzieży wypowiedzi samego papieża. Warto tylko nadmienić, że ukazało się co najmniej kilkanaście takich pozycji, z których większość ma formę antologii ${ }^{4}$. Korzystanie z bogatej spuścizny piśmienniczej Karola Wojtyły jest oczywiście naturalnym i nader częstym zabiegiem w pracach innych autorów, poświęconych papieżowi i jego nauczaniu. Stąd również w analizowanym przez nas zbiorze pojawiają się fragmenty bezpośrednio zaczerpnięte $\mathrm{z}$ jego nauki ${ }^{5}$. Trzeba także nadmienić, że opisywane teksty dla dzieci i młodzieży stanowią stosunkowo niewielki odsetek ogółu produkcji wydawniczej poświęconej Janowi Pawłowi II ${ }^{6}$.

3 Por. Pokolenie JP II. Przeszłość i przyszłość zjawiska religijnego, pod red. T. Szawiela, Warszawa 2008; P. Zuchniewicz, Narodziny pokolenia JP 2, Warszawa 2007.

${ }^{4}$ Na przykład Jan Paweł II do dzieci, wybór tekstów G. Grochowski, Sandomierz 2005; Jan Paweł II, List do dzieci, Warszawa 2007; Jan Paweł II - spotkania z dziećmi, wybór tekstów R. Bocian, Częstochowa 2007; Podręcznik pokolenia JP 2. Ojcowskie słowa do młodych świata, Polski i Lednicy, pod red. H. Koźmińskiej, Poznań 2008; Halo urwisy! Tu mówi Papież. Słowa Jana Pawła II do dzieci, oprac. D. Madejczyk, Kielce 2000; Wy jesteście nadzieją świata! Jan Paweł II do młodzieży, oprac. A. Wojciechowska, Kraków 2005.

${ }^{5}$ E. Berndsen, Pieśń o chłopcu spod wadowickiego błękitu, Bielsko-Biała 2006, s. $30-31$.

${ }^{6}$ Por. J. Wolak, Tytuły, tematy, tendencje, [w:] K. Frołow, J. Wolak, Raport o książce katolickiej. Edycja 2007, Warszawa 2007, s. 12-13. 


\section{Chronologia i geografia wydawnicza}

W latach 1989-2009 na polskim rynku wydawniczym pojawiło się blisko 40 pozycji $^{7}$ mieszczących się w interesującej nas kategorii, przy czym niektóre z nich miały więcej niż jedno wydanie. Uwagę zwraca charakterystyczna tendencja rynkowa, przejawiająca się w wyraźnym okolicznościowym wzroście publikacji oraz wznowień bezpośrednio po śmierci papieża w 2005 r. $^{8}$ (zob. tab. 1).

Tabela 1. Książki o Janie Pawle II przeznaczone dla dzieci i młodzieży według lat wydania

\begin{tabular}{|l|c|c|}
\hline \multicolumn{1}{|c|}{ Rok } & Liczba tytułów & W tym wznowienia \\
\hline Do 1989 r. & 3 & 2 \\
\hline $1990-1996$ & - & - \\
\hline 1997 & 1 & - \\
\hline 1998 & 2 & - \\
\hline 1999 & 2 & - \\
\hline 2000 & 1 & - \\
\hline 2001 & 1 & - \\
\hline 2002 & 1 & 1 \\
\hline
\end{tabular}

${ }^{7}$ Pierwszorzędną rolę w obliczeniach statystycznych, jak również kategoryzacji poszczególnych tytułów odegrał dostępny w Internecie „Przewodnik Bibliograficzny. Urzędowy Wykaz Druków Wydanych w Rzeczypospolitej Polskiej” (http://www.bn.org.pl/ katalogi-i-bibliografie). Mając świadomość, że z uwagi na niewielką objętość części książeczek (kilka stron) oraz dominującą rolę ilustracji niektóre interesujące nas publikacje nie będą zarejestrowane w tym podstawowym członie systemu bieżącej bibliografii narodowej, wykorzystano także Katalog Główny Biblioteki Narodowej (część nieodnotowanych w „Przewodniku Bibliograficznym” książeczek jest dostępna w Czytelni Dokumentów Życia Społecznego Biblioteki Narodowej). Wyłoniony w ten sposób zbiór został dodatkowo uzupełniony o kilka pozycji, które zostały odnalezione w dostępnych na stronach WWW księgarniach internetowych, portalach poszczególnych wydawnictw oraz katalogach bibliotek (m.in. korzystano z Katalogu Rozproszonego Bibliotek Polskich). Wszystkie zaklasyfikowane pozycje poddano badaniu z autopsji (korzystając ze zbiorów Biblioteki Jagiellońskiej, Biblioteki Narodowej, Muzeum Książki Dziecięcej w Warszawie, kilkunastu bibliotek publicznych na terenie Krakowa i Warszawy oraz dokonując licznych zakupów w księgarniach i na aukcjach internetowych).

${ }^{8}$ Por. E. Chuchro, Przewodnik po książkach papieskich, „Nowe Książki” 2008, nr 10, s. 78-79; J. Wolak, dz. cyt., s. 17. 
Tabela 1. Książki o Janie Pawle II przeznaczone dla dzieci i młodzieży według lat wydania (ciąg dalszy)

\begin{tabular}{|l|c|c|}
\hline \multicolumn{1}{|c|}{ Rok } & Liczba tytułów & W tym wznowienia \\
\hline 2003 & 3 & - \\
\hline 2004 & 4 & - \\
\hline 2005 & 8 & 2 \\
\hline 2006 & 11 & 1 \\
\hline 2007 & 3 & - \\
\hline 2008 & 4 & - \\
\hline 2009 & 3 & $\mathbf{8}$ \\
\hline Razem & $\mathbf{4 7}$ & 2 \\
\hline
\end{tabular}

Źródło: obliczenia własne; por. przypis 7.

Najstarszym tekstem o Karolu Wojtyle uwzględnionym w niniejszym zestawieniu jest książka księdza Mieczysława Malińskiego Najchętniej grał na bramce ${ }^{9}$, wydana dwukrotnie w $1983 \mathrm{r}^{10}$ Powyższe pozycje ukazały się jeszcze za czasów PRL-u i temu też należy przypisać ich ubogą formę edytorską. Stanowią one popularne, pisane anegdotycznym językiem opracowania biograficzne, uzupełnione jedynie czarno-białymi fotografiami pochodzącymi z archiwum Artura Mari. Warto podkreślić, że przez długie lata były to w zasadzie jedyne książki na ten temat przeznaczone dla młodzieży ${ }^{11}$.

Kolejne wydawnictwa adresowane do młodego czytelnika poświęcone papieżowi powstały dopiero w końcu lat 90., a więc prawie w dekadę po przemianach politycznych i gospodarczych, zapoczątkowanych w 1989 r. Ich ukazanie się stanowiło zapewne jeden z przejawów rozwijającej się specjalizacji na rynku księgarskim. Z kilkudziesięciu odnotowanych pozycji tylko siedem zostało wydanych w więcej niż jednej edycji. Warto zauważyć, że adaptacją książki Nasz papież Mieczysława Malińskiego jest powstałe w końcu lat 90. opowiadanie Przyjaciel ludzi ${ }^{12}$, publikowane także później pod zmienionym tytułem Przyjaciel ludzi dużych

\footnotetext{
${ }_{9}$ M. Maliński, Najchętniej grał na bramce, Warszawa 1983; wyd. 2: Warszawa 1985.

${ }_{10}$ Wydanie rozszerzone pod zmienionym tytułem. Zob. M. Maliński, Nasz papież, Warszawa 1983; wyd. 2: Kraków 1986.

${ }_{11}$ Miały one charakter popularyzatorski i mogły być także czytane przez dorosłych.

12 M. Maliński, Przyjaciel ludzi. O papieżu dla dzieci, Łódź 1998.
} 
i małych ${ }^{13}$. Również $\mathrm{w}$ przypadku niektórych innych książek kolejne wydania cechowały się pewnymi zmianami w tytule oraz treści. Dla przykładu, wydrukowany w 2006 r. papieski poemat Emilii Berndsen Pieśń o chłopcu spod wadowickiego błękitu ${ }^{14}$ ukazał się rok później nakładem Ludowej Spółdzielni Wydawniczej pod zmienionym tytułem Pieśń o chłopcu spod wadowickiego nieba ${ }^{15}$. W stosunku do pierwszego wydania utwór został zmniejszony o kilka przygodnych wierszy zawartych w części Wierzę w Świętych Obcowanie, napisanych przez autorkę po śmierci papieża.

Rynek wydawców książek o Janie Pawle II przeznaczonych dla dzieci i młodzieży charakteryzuje się dużym rozproszeniem. Pozycje takie zostały przygotowane przez 35 wydawnictw, przy czym 11 z nich wprowadziło na rynek więcej niż jedną książkę (tab. 2).

Tabela 2. Wydawnictwa najczęściej drukujące książki o Janie Pawle II przeznaczone dla dzieci i młodzieży

\begin{tabular}{|l|c|}
\hline \multicolumn{1}{|c|}{ Wydawnictwo } & Liczba wydań \\
\hline Diecezjalne w Sandomierzu & 6 \\
\hline Rubikon & 3 \\
\hline Adryfa & 2 \\
\hline Biały Kruk & 2 \\
\hline Duszpasterstwa Rolników & 2 \\
\hline DW Rafael & 2 \\
\hline Edycja św. Pawła & 2 \\
\hline Espe & 2 \\
\hline Siedmioróg & 2 \\
\hline WKA Tum & 2 \\
\hline Sióstr Loretanek & 2 \\
\hline
\end{tabular}

Źródło: obliczenia własne; por. przypis 7.

W analizowanej grupie przeważają oficyny katolickie, takie jak: Wydawnictwo Diecezji Sandomierskiej, Wydawnictwo Archidiecezji Łódz-

${ }^{13}$ Tenże, Przyjaciel ludzi dużych i małych, Wrocław 2002 oraz Wrocław 2005.

${ }^{14}$ E. Berndsen, Pieśń o chłopcu spod wadowickiego błękitu...

15 Taż, Pieśń o chłopcu spod wadowickiego nieba, Warszawa 2007. 
kiej $^{16}$, Krakowskiej (św. Stanisława BM) ${ }^{17}$, Wydawnictwo Duszpasterstwa Rolników z Włocławka ${ }^{18}$, Wydawnictwo Karmelitów Bosych ${ }^{19}$. Konfrontując listę książek „papieskich” dla dzieci i młodzieży z zestawieniem określającym udziały rynkowe poszczególnych oficyn, należy odnotować brak aktywności na tym polu takich uznanych firm, jak krakowskie Wydawnictwo WAM oraz kielecka Jedność, przy czym w tym drugim przypadku jest to o tyle zaskakujące, że mamy do czynienia z firmą specjalizującą się w edycjach literatury katolickiej przeznaczonej dla młodego czytelnika ${ }^{20}$. Co najmniej kilka książek zostało wydanych nakładem oficyn świeckich, kojarzonych jednak ze światopoglądem chrześcijańskim, jak np. Znak. Inną grupę stanowią potentaci na rynku mediów dla dzieci i młodzieży, niezwiązani bezpośrednio z opcją katolicką, np. Siedmioróg, Media Rodzina czy Świat Książki koncernu Bertelsmann Media. Warto wreszcie wspomnieć o szeregu lokalnych oficyn, np. Multikram Rypin czy Wydawnictwo Śląskie ABC z Rybnika. Liderem listy jest sandomierskie wydawnictwo diecezjalne wyspecjalizowane w dziecięcej i młodzieżowej literaturze katolickiej ${ }^{21}$, które ma na swoim koncie rozpowszechnioną w wysokim nakładzie $^{22}$ opowieść Joanny Krzyżanek Jan Paweł II, czyli jak Karolek został papieżem $^{23}$. Pozycja ta doczekała się wznowienia ${ }^{24}$ oraz kontynuacji w postaci drugiego tomu ${ }^{25}$, a także wersji w języku słowackim ${ }^{26}$. Wydawnictwo edukacyjne Rubikon wprowadziło na rynek dwa tytuły związane z nurtem młodzieżowym, stanowiące jednak raczej pomoc metodyczną dla nauczycieli i katechetów, przybliżających w ramach lekcji osobę Jana Pawła II ${ }^{27}$.

\footnotetext{
${ }^{16}$ Wydawca książki M. Malińskiego, Przyjaciel ludzi...

${ }^{17}$ Wydawca książki F. Bucarellego, Listy dzieci do Karola, Kraków 2008.

18 K. Tomaszewicz, O Lolku, który został papieżem, Włocławek 2003; Szukałem Was... Inscenizacje na Dzień Papieski, Włocławek 2005.

${ }_{19}$ Wydawca niewielkiej kolorowanki z tekstem Arkadiusza Wanata i ilustracjami Anny Wiraszki, Jan Paweł II, Kraków 2006.

${ }^{20}$ Por. K. Frołow, J. Wolak, Raport o książce katolickiej. Edycja 2007, Warszawa 2007, s. $50-53$.

21 Tamże, s. 26-27 i 53.

${ }^{22}$ Tylko w 2005 r. sprzedano 115 tys. jej egz. Por. J. Wolak, dz. cyt., s. 26.

23 J. Krzyżanek, Jan Paweł II, czyli jak Karolek został papieżem, Sandomierz 2005.

24 Wydanie drugie ukazało się w $2006 \mathrm{r}$.

${ }^{25}$ J. Krzyżanek, O tym, jak Jan Paweł II kilkadziesiąt razy okrążył kulę ziemska, Sandomierz 2006.

${ }^{26}$ Taż, Jan Pavol II. Alebo ako sa Karolko stal papežom, Sandomierz 2008.

27 Szukałem Was... Scenariusze lekcji wychowawczych dla pokolenia Jana Pawła II, pod red. T. Król, Kraków 2005; Zagrajmy dla papieża, pod red. T. Król, Kraków 2005; wyd. 2: 2006.
} 
Wspomniane rozproszenie ośrodków wydawniczych jest także zauważalne przy analizie miejsc edycji. W sumie na utworzonej liście odnotowano 18 ośrodków, obok dużych metropolii, takich jak Warszawa, Wrocław czy Kraków, pojawiła się tu również kojarzona z Kościołem Częstochowa oraz kilka mniejszych miast o znaczeniu typowo lokalnym (Legnica, Rypin, Szarowola). Warto podkreślić, że najważniejszym ośrodkiem propagującym postać Jana Pawła II wśród dzieci i młodzieży jest mocno związany z jego biografią Kraków, w którym ukazało się 15 pozycji wydanych przez 9 firm (zob. tab. 3).

Tabela 3. Najczęstsze miejsca wydawania książek dla dzieci i młodzieży o Janie Pawle II

\begin{tabular}{|l|c|c|}
\hline \multicolumn{1}{|c|}{ Miejscowość } & Liczba wydawnictw & Liczba pozycji \\
\hline Kraków & 9 & 15 \\
\hline Warszawa & 8 & 8 \\
\hline Sandomierz & 1 & 6 \\
\hline Wrocław & 2 & 4 \\
\hline Częstochowa & 1 & 2 \\
\hline Łódź & 2 & 2 \\
\hline Poznań & 2 & 2 \\
\hline Włocławek & 1 & 2 \\
\hline Gorzeń Górny & 1 & 2 \\
\hline
\end{tabular}

Źródło: obliczenia własne; por. przypis 7.

Autorzy

A utorami kilku interesujących nas pozycji są osoby duchowne. Największe zasługi w tym zakresie ma ksiądz Mieczysław Maliński, przyjaciel z lat młodzieńczych przyszłego papieża, świadek wielu istotnych wydarzeń z jego życia, autor obszernych biografii Karola Wojtyły ${ }^{28}$.

${ }^{28}$ Pierwsze z nich to wznawiane kilkukrotnie: Droga do Watykanu, Warszawa 1979, i Wezwano mnie z dalekiego kraju, Poznań 1980. Na informacje zawarte w jego pracach powołują się praktycznie wszyscy polscy i zagraniczni biografowie Jana Pawła II, por. np. B. Lecomte, dz. cyt., s. 97, 371; P. Zuchniewicz, Lolek. Młode lata papieża, Warszawa 2008, s. $240-241,310 \mathrm{i}$ in. 
Wspomniane wcześniej publikacje ${ }^{29}$ są tylko niewielką częścią twórczości literackiej krakowskiego kapłana poświęconej postaci Jana Pawła II. W dorobku pijara Stefana Denkiewicza znajduje się książeczka Z Piotrem nowych czasów ${ }^{30}$. Wśród księży uwagę zwracają jeszcze dwie osoby: jezuita ojciec Wacław Oszajca ${ }^{31}$, dziennikarz i wykładowca Uniwersytetu Warszawskiego, autor adresowanej do dzieci, pięknie ilustrowanej historii pod tytułem Nasz przyjaciel Papież. Jan Paweł $I^{32}$, oraz poznański dominikanin, ojciec Jan Góra, założyciel Domu Papieskiego, organizator młodzieżowych zlotów nad jeziorem Lednica. $W$ jego opowieści o wymownym tytule Nie lękajcie się! narrator wciela się w postać Jana Pawła II ${ }^{33}$. Obecność duchowieństwa w twórczości poświęconej zmarłemu w 2005 r. papieżowi przejawia się także we wstępach oraz posłowiach, w których dostojnicy kościelni uwiarygodniają swoim komentarzem literacki przekaz. Tego typu wypowiedzi najczęściej towarzyszą antologiom tekstów dziecięcych, np. wiersze gimnazjalistów z Radgoszczy zostały poprzedzone słowem biskupa tarnowskiego Wiktora Skworca ${ }^{34}$, a literackie i plastyczne prace konkursowe z Podlasia zostały opatrzone krótką notką sygnowaną przez biskupa siedleckiego Henryka Tomasika ${ }^{35}$. Komentarzem dla polskiego czytelnika autorstwa ks. prałata Sławomira Odera ${ }^{36}$ poprzedzono Listy dzieci do Karola Franca Bucarellego, natomiast pierwszy w historii komiks o polskim papieżu uzyskał rekomendację kardynała Paula Pouparda, przewodniczącego Papieskiej Rady do spraw Kultury ${ }^{37}$. Niektóre z tych tekstów mają charakter czysto oficjalny, kilka natomiast odwołuje się do osobistych kontaktów hierarchów z polskim papieżem. W tego typu wypowiedziach, poza rozlicznymi podziękowaniami i pochwałami, możemy odnaleźć ciekawe anegdoty wzbogacające naszą wiedzę o życiu

${ }^{29}$ M. Maliński, Najchętniej grał...; tenże, Nasz papież...; tenże, Przyjaciel ludzi...

30 S. Denkiewicz, Z Piotrem nowych czasów, Kraków 2004.

${ }^{31}$ O. mgr W. Oszajca [on-line]. Instytut Dziennikarstwa UW. Pracownicy [dostęp 10 sierpnia 2010]. Dostępny w World Wide Web: http://www.id.uw.edu.pl/pracownicy/woszajca.

32 W. Oszajca, Nasz przyjaciel Papież. Jan Paweł II, Warszawa 2007.

${ }^{33}$ J. W. Góra, Jan Paweł II. Nie lękajcie się!, Poznań 2008.

${ }^{34} Z$ potrzeby uczniowskiego serca. Tomik wierszy dedykowanych Ojcu Świętemu, Tarnów 2004, s. 5-6.

${ }^{35}$ Jan Paweł II. Papież, jakiego znam i podziwiam, pod red. ks. S. Chodźki, Siedlce 1999, s. 5.

36 „Postulatora Procesu Beatyfikacji i Kanonizacji Sługi Bożego Jana Pawła II”, F. Bucarelli, dz. cyt., s. 4-6.

37 D. Bar, L. B. Koch, G. Lehideux, Z Wadowic do Rzymu. Dzieje życia Karola Wojtyły Jana Pawła II, Kraków 2005, s. 2. 
Jana Pawła II. Istotnym znakiem kontroli nad treścią prac traktujących o papieżu jest imprimatur, czyli zezwolenie na druk materiałów zgodnych treściowo z nauką Kościoła. W przypadku interesującego nas tematu było ono jednak raczej przejawem nobilitacji treści i nie pojawiało się w większości publikacji. Zezwolenie takie miały tylko niektóre pozycje przygotowane przez wydawnictwa katolickie ${ }^{38}$.

Wśród autorów zdecydowanie przeważają osoby świeckie. Należą do nich m.in. krajanie Karola Wojtyły: urodzona pod Andrychowem poetka Emilia Berndsen ${ }^{39}$ oraz pochodzący spod Wadowic poeta i prozaik, piewca „małej ojczyzny” i kontynuator tradycji gorzeńskiego „Czartaka” - Adam Ryszard Fajfer ${ }^{40}$. Szereg twórców literatury dla dzieci i młodzieży sięgnęło po papieski temat w celu popularyzacji życiorysu wielkiego Polaka. Z takiej inicjatywy powstały: opowieść Mariusza Wollnego ${ }^{41}$, poemat dziecięcy Ewy Stadtmueller ${ }^{42}$ oraz towarzyszące szerszemu przedsięwzięciu multimedialnemu wierszowane, pięknie ilustrowane wydawnictwo Łukasza Dębskiego, Anny Kaszuby-Dębskiej i Justyny Kiliańczyk-Zięby Felicjanek $10^{43}$.

Kilka odnotowanych książek to tłumaczenia. Dotyczy to m.in. pierwszego w świecie komiksu o Janie Pawle II $^{44}$, a także wzruszającej antologii dziecięcych listów, zredagowanych przez włoskiego dziennikarza Franca Bucarellego ${ }^{45}$. Wypada podkreślić, że zwłaszcza w przypadku książek przeznaczonych dla dzieci młodszych szczególną rolę odgrywały ilustracje. Niektórzy autorzy tekstów i ilustratorzy wielokrotnie podejmowali współpracę, czego efektem są powtarzające się kilkukrotnie nazwiska, np. Agaty Elżbiety Drewniany związanej ze wspomnianym wyżej wadowickim poetą ${ }^{46}$ czy Marcina Ciseło, współpracującego z Joanną Krzyżanek przy papieskiej dylogii ${ }^{47}$. Warto też wspomnieć o słynnym rysowniku Edwardzie

\footnotetext{
${ }^{38}$ Na przykład Wydawnictwo Duszpasterstwa Rolników we Włocławku. 2006.

39 Autorka zbioru wierszy Pieśń o chłopcu spod wadowickiego błękitu, Sułkowice

${ }^{40}$ Autor książeczek: Za co dzieci kochaja Jana Pawła II, Gorzeń Górny 2006, i O Janie Pawle II, który zło zwyciężał dobrem, Gorzeń Górny 2006.

${ }^{41}$ M. Wollny, Jak Lolek został papieżem, Kraków 2009.

${ }^{42}$ E. Stadtmueller, Z Wadowic do nieba, Kraków 2006.

${ }^{43}$ Ł. Dębski, A. Kaszuba-Dębska, J. Kiliańczyk-Zięba, Felicjanek 10, Warszawa 2008.

44 D. Bar, L. B. Koch, G. Lehideux, dz. cyt.

${ }^{45}$ F. Bucarelli, dz. cyt.

${ }^{46}$ A. R. Fajfer, Za co dzieci kochają...; tenże, O Janie Pawle II...

${ }^{47}$ J. Krzyżanek, Jan Paweł II, czyli jak Karolek został papieżem, Sandomierz 2006, s. 72; taż, O tym, jak Jan Paweł II..., s. 144.
} 
Lutczynie, który ozdobił opowieści księdza Mieczysława Malińskiego Przyjaciel ludzi dużych i małych ${ }^{48}$. Wiele z interesujących nas pozycji wykorzystuje oryginalne zdjęcia papieża pochodzące np. z pielgrzymek do Polski. Przynajmniej w czterech przypadkach fotografie wykonał Włoch Arturo Mari, znany z wieloletniej współpracy ze Stolicą Apostolską ${ }^{49}$.

\section{Formy przekazu}

7 właszcza w ostatnich latach istotnym elementem książek o papieżu staLły się dołączane gadżety w postaci komunijnych karteczek, naklejek, map pielgrzymek, a nawet płyt DVD. Postać Jana Pawła II przybliżano dzieciom i młodzieży z wykorzystaniem różnorodnych form przekazu (tab. 4).

Tabela 4. Książki o Janie Pawle II według form przekazu

\begin{tabular}{|l|c|}
\hline \multicolumn{1}{|c|}{ Forma } & Liczba pozycji \\
\hline Opowiadanie & 10 \\
\hline Poezja & 6 \\
\hline Epistolografia & 5 \\
\hline Publicystyka (pogadanka, felieton, opis) & 5 \\
\hline Kolorowanka & 4 \\
\hline Inscenizacja & 4 \\
\hline Beletryzowana biografia & 3 \\
\hline Komiks & 2 \\
\hline Poemat & 2 \\
\hline Teksty metodyczne & 1 \\
\hline Rozrywki umysłowe & 1 \\
\hline Formy mieszane* & 4 \\
\hline
\end{tabular}

* Tj. takie, gdzie w obrębie jednej pozycji występuje więcej niż jedna z wymienionych form, np. zbiór tekstów pt. Ojcze Święty, chcę Ci powiedzieć..., Legnica 1997, s. 73, obejmuje oprócz prac plastycznych zarówno poezje, jak i listy.

Źródło: obliczenia własne; por. przypis 7.

${ }^{48}$ M. Maliński, Przyjaciel ludzi dużych i małych...

${ }^{49}$ W licznych przypadkach w analizowanych książkach nie ma informacji o autorach zdjęć, a jedynie o archiwach, z których pochodzą fotografie. 
Najwięcej pozycji ma postać tradycyjnych opowiadań, na drugim miejscu należy wymienić opracowania odwołujące się do ekspresji poetyckiej. Warto jednak odnotować pojawienie się na naszym rynku wielu innych ciekawych sposobów przekazywania wiedzy o Janie Pawle II. Najbardziej popularne, poza opowiadaniami i poezją, są edycje listów dziecięcych adresowanych do polskiego papieża. Stanowią one świadectwo nieustannego duchowego kontaktu pomiędzy dziećmi a głową Kościoła:

To, co stanowi element wspólny wszystkich tych małych-wielkich dzieł, to wielka miłość, która z nich emanuje. Dla wszystkich z Was Jan Paweł II jest po prostu kimś bliskim, kochanym, dobrym, jak członek rodziny ${ }^{50}$.

Listy wydane w Polsce są owocem zarówno lokalnych, głównie szkolnych inicjatyw, jak i stanowią szersze antologie obejmujące epistolografię dziecięcą z obszaru całej Polskii ${ }^{51}$, a nawet świata ${ }^{52}$. Specyfika percepcji młodego widza powodowała, że wydawcy zwracali szczególną uwagę na graficzną szatę książki. Przygotowano nawet komiksy o papieżu ${ }^{53}$, a także książeczki do kolorowania ${ }^{54}$ przeznaczone dla młodszych dzieci. Warto przy tym zauważyć, że pomysły komiksowej wersji historii o Janie Pawle II powstały za granicą (we Francji), stąd też odznaczają się one specyficzną wizją polskiego społeczeństwa i rozpoczętego w tym kontekście pontyfikatu, co nie umknęło uwadze naszym rodzimym recenzentom ${ }^{55}$. Pojawienie się komiksów o polskim papieżu wzbudziło sporo kontrowersji. Krytykowano nie tyle lekką formę takich publikacji, ile swoistą skrótowość tekstu, charakterystyczną dla tej formy artystycznej, zmuszającą niestety do banalizacji treści, oraz niską jakość strony ilustracyjnej ${ }^{56}$. In-

\footnotetext{
${ }^{50}$ F. Bucarelli, dz. cyt., s. 4.

${ }^{51}$ Listy sercem pisane, red. i oprac. Z. Kras, J. Stala, Kraków 2003.

52 F. Bucarelli, dz. cyt.

${ }_{53}$ T. Pagot, Jan Paweł II papież trzeciego tysiąclecia. Ilustrowana historia życia Papieża Polaka, Kraków 2001; D. Bar, L. B. Koch, G. Lehideux, dz. cyt.

${ }^{54}$ K. Śliwińska, Nasz papież Jan Paweł II. Książeczka do kolorowania, Poznań 2005; A. Wiraszka, A. Wanat, Jan Paweł II. Malowanka, Kraków 2006; A. Nowicki, M. Wilk, Jan Paweł II - przyjaciel dzieci. Książeczka do kolorowania, Częstochowa 2006; P. Gazda, Papież Jan Paweł II, Wrocław 2007.

55 Por. kog, Wyszedł francuski komiks o Papieżu. Gazeta Wyborcza [on-line] z dn. 5.12.2004 [dostęp 10 sierpnia 2010]. Dostępny w World Wide Web: http://wiadomosci. gazeta.pl/wiadomosci/1,53600,2430520.html.

${ }^{56}$ Por. E. Chuchro, dz. cyt., s. 78-79.
} 
nym sposobem dynamicznego przedstawiania papieskiej historii było zamieszczenie tekstów scenicznych przeznaczonych do wystawiania, np. w ramach lekcji katechezy ${ }^{57}$, albo przetworzonych na język filmowej animacji ${ }^{58}$.

\section{Specyfika ujmowania treści}

Eabuły związane z papieżem odwoływały się zwykle do dwóch podsta- wowych schematów. Większa część tekstów ukazywała historię Jana Pawła II, nawiązując do faktycznych epizodów z jego życia. Naturalne ramy czasowe opowieści wyznaczały narodziny i śmierć papieża ${ }^{59}$. Taki tradycyjny układ bywał niekiedy dynamizowany poprzez zastosowanie techniki retrospekcji ${ }^{60}$. W kilku przypadkach autor w szczególny sposób eksponował jakąś wybraną część biografii ${ }^{61}$. Zdarzało się również, że akcja obejmowała jedynie fragment życia papieża - np. dotyczyła jego zagranicznych misji apostolskich ${ }^{62}$, ewentualnie nawiązywała do istotnych epizodów biograficznych, np. rozmowy z Ali Agcą we włoskim więzieniu ${ }^{63}$. Szczególnym zainteresowaniem autorów cieszyły się młode lata „Lolka”, pozwalały one bowiem ukazać postać nietuzinkowego bohatera w adekwatnej do dziecięcej wyobraźni perspektywie. Opowiadania pisane według powyższego schematu miały charakter beletryzowanych biografii bądź też były ujęte $\mathrm{w}$ ramy historii relacjonowanej konkretnemu dziecku zafrapowanemu życiem niezwykłego bohatera ${ }^{64}$. Ta druga konstrukcja umożliwiała stworzenie dodatkowej relacji pomiędzy postaciami, historia

${ }^{57}$ Zagrajmy dla papieża, pod red. T. Król, Kraków 2006, s. 168.

${ }^{58}$ Ł. Dębski, A. Kaszuba-Dębska, J. Kiliańczyk-Zięba, Felicjanek 10...

59 Oczywiście, w przypadku książek napisanych przed 2005 r. fabuły miały charakter otwarty, por. M. Maliński, Nasz papież...

${ }^{60} \mathrm{~K}$. Tomaszewicz, dz. cyt. Ta obszerna praca ma charakter opowieści dygresyjnej. Biografia Karola Wojtyły nie jest w niej relacjonowana zgodnie z chronologią, a kolejne momenty z jego życia pojawiają się bez zachowania zasady jedności czasu, miejsca i bohatera.

${ }^{61}$ Na przykład M. Wollny, dz. cyt., koncentruje się głównie na młodych latach późniejszej głowy Kościoła (ponad 100 stron tekstu), podczas gdy okres pontyfikatu opisuje w skrócie na kilkunastu stronach. Z kolei X. Lecoeur, Jan Paweł II. Niezłomny $w$ wierze, Warszawa 2006, s. 12-18, w komiksowym fragmencie skupia swoją uwagę na pontyfikacie, choć poprzedza go niewielkim wstępem mówiącym o pochodzeniu papieża.

${ }^{62}$ J. Krzyżanek, $O$ tym, jak Jan Paweł II...

${ }^{63}$ M. Rosiak, Rozmowa, [w:] Szukałem Was... Inscenizacje na Dzień Papieski..., s. 65-71.

${ }^{64}$ M. Bednarska-Moskwa, Opowieść o Wielkim Papieżu, Kraków 2007, s. 5. 
Karola Wojtyły stanowiła bowiem płaszczyznę porozumienia między osobą starszą (mamą, babcią, ciocią) a dziećmi. Relacje międzypokoleniowe stanowiły w tym przypadku jeden $\mathrm{z}$ istotnych elementów dydaktycznych opowieści ${ }^{65}$. Oryginalnym pomysłem na przedstawienie postaci papieża było przygotowanie opowiadania o nim w narracji pierwszoosobowej. Ojciec Jan Góra wykorzystał swoją osobistą znajomość z Karolem Wojtyłą, wplatając w tekst niemal „żywe” papieskie kwestie przekazywane z charakterystyczną bezpośredniością, dowcipem oraz dobroduszną ironią:

Co ten Góra znowu wymyślił?! Przywiózł do mnie swoją młodzież, jakiś chór, jakichś górali i jakieś balety. Kiedy ich dopuścili do mnie, baletnice wznosiły się jak anioły. Ochrona starała się ich uspokoić i sprowadzić na ziemię, ale się nie dali. Góra zwinął mi z kolan chusteczkę do nosa ${ }^{66}$.

Charakterystyczna jest tu także perspektywa wydarzeń komentowana przez głównego bohatera jakby spoza grobu, co stanowi zaskakującą puentę:

Odchodząc do domu Ojca, powiedziałem wszystkim, którzy byli w pobliżu, na pożegnanie, Amen. Nie obawiam się śmierci, bo życie spełniłem jeszcze przed śmiercią, i nie przeraża mnie zgon, bo umiałem żyć pięknie, więc odchodzę z tego świata, nie trzaskając drzwiami. Pod moimi oknami gromadzi się młodzież z całego świata. Przez całe życie ich szukałem. Teraz oni przyszli do mnie. Cicho zamykam drzwi. Jest godzina 21.37. Tę godzinę ludzie zapamiętali i łączą się ze mną w modlitwie nawet po moim odejściu. W ten sposób żyję w ich sercach. Do mojego okna przyleciały białe gołębie ${ }^{67}$.

W polskiej tradycji powieściowej szczególne miejsce zajmowała hagiografia, której elementy bardzo często były wykorzystywane w dziełach biograficznych przeznaczonych dla młodego pokolenia, mających przedstawiać określone rysy moralne bohaterów i przeprowadzać swoistą apologetykę narodowych mitów ${ }^{68}$. Osoba papieża, pomimo całej bezprece-

\footnotetext{
${ }^{65}$ Na przykład K. Tomaszewicz, dz. cyt., s. 7-42.

${ }^{66}$ J. W. Góra, dz. cyt., s. 55.

${ }^{67}$ Tamże, s. 60

${ }^{68}$ Por. J. Szymkowska-Ruszała, Zbeletryzowane biografie dla dzieci i młodzieży (1918-1939), Słupsk 1985, s. 28-37.
} 
densowości jego pontyfikatu, dobrze wpisywała się w taki apologetyczny scenariusz. Nie da się ukryć, że przynajmniej w części książek o Karolu Wojtyle zastosowano szereg zabiegów formalnych i stylistycznych, mających na celu nadanie wyjątkowej rangi opisywanemu bohaterowi. Sam sposób narracji podlegał niekiedy swoistej baśniowej stylizacji:

Ta piękna historia rozpoczęła się w małym miasteczku nieopodal Krakowa. [...] Właśnie tam, dawno temu, żyła sobie rodzina państwa Wojtyłów [...]. Często prosili Boga, by dał im jeszcze jednego potomka. Wiosną 1920 roku ich marzenia spełniły się. 18 maja w domu państwa Wojtyłów rozległ się płacz nowo narodzonego dziecka. Pani Emilia powiła ślicznego chłopca, któremu po ojcu dano na imię Karol.Dumny tata i rozradowany starszy brat pochylili się nad kołyską, aby powitać nowego członka rodziny ${ }^{69}$.

Uroczysty i wzniosły charakter mogło mieć także rozpoczęcie samej opowieści, czyli moment narodzin człowieka, którego wierni zaraz po śmierci uznali za świętego:

Tego dnia od samego rana działy się różne dziwne rzeczy. Wyjątkowo pięknie pachniały bzy, koty - zamiast wylegiwać się na słońcu - maszerowały wokół domu, wszystkie wadowickie wróble siedziały na parapetach i cichutko ćwierkały ${ }^{70}$.

Znacznie ciekawsze jednak, niż przytoczone powyżej przykłady apokryficznych rozwiązań fabularnych, były próby wykorzystania mniej szablonowej symboliki arealnej, odnoszącej się do „podążania” Jana Pawła II ku świętości. Taką rolę odgrywała np. fruwająca nad miastem papieska piuska, mogąca stanowić dar dla przypadkowego przechodnia ${ }^{71}$. Podobne znaczenie miał proroczy sen „lotniczy” małego Lolka, w którym pojawił się szerszy kontekst literacki z nawiązaniami do Pana Twardowskiego oraz powietrznej epopei Nilsa Holgerssona z powieści Selmy Lagerlöf ${ }^{72}$.

\footnotetext{
${ }^{69}$ J. Majewska, Opowiem ci o Janie Pawle II, Wrocław 2005, s. 6.

${ }^{70}$ J. Krzyżanek, Jan Paweł II, czyli jak Karolek został papieżem, Sandomierz 2006, s. 6.

${ }^{71}$ Ł. Dębski, A. Kaszuba-Dębska, J. Kiliańczyk-Zięba, Felicjanek 10..., s. [57-58].

${ }^{72}$ Por. M. Wollny, dz. cyt., s. 8-10.
} 
Wyjątkowość powołania małopolskiego duchownego niejednokrotnie podkreślały wzniosłe, poetyckie tytuły utworów: Pieśń o chłopcu spod wadowickiego błękitu, Opowieść o Wielkim Papieżu, jak również te odnoszące się do metaforyki ziemskiej podróży: $Z$ Wadowic do Rzymu, Z Wadowic do nieba. Na drugim biegunie pojawiły się jednak określenia lżejsze, akcentujące raczej ludzki wymiar papieskiej pielgrzymki: Przyjaciel ludzi dużych i małych, Jak Lolek został papieżem, Za rękę z papieżem. Taka dwoistość widzenia postaci Jana Pawła II wynikała oczywiście z samego sposobu bycia „Piotra naszych czasów” oraz była zgodna z personalistycznym rozumieniem edukacji dziecka. Teksty często dokonywały oceny postępowania poszczególnych bohaterów, prowadziły do konfrontacji określonych postaw oraz wywoływały u czytelnika na zasadzie analogii uczucie empatii:

Gdy wrócił ze szkoły i podszedł pod dom, spotkał oczekującą go nauczycielkę i zarazem sąsiadkę rodziny. Przytuliła do siebie opierającego się trochę Lolka i powiedziała: twoja mama nie żyje.

Nie bardzo to do niego dotarło. Wyrwał się i wbiegł do domu. Tam paraliżujący ból i zimno ściskające dziesięcioletnie serce były reakcją na straszliwie bolesną prawdę. [...] 0 mamie nigdy nie zapomniał. Po latach napisał: „Nad Twoją białą mogiłą, o Matko, zgasłe Kochanie - za całą synowską miłość modlitwa: daj wieczne odpoczywanie".

Babunia i bliźniaki doszli do kościoła. Dzieci nic nie mówiły, tylko mocniej trzymały się ręki babuni, a ona szeptała modlitwy, wypraszając Boże łaski dla swoich skowroneczków. Po Mszy świętej z kościoła wyszli weselsi.

- Modliłam się, żeby mama i tata żyli jak najdłużej - szepnęła do brata Małgosia.

- A ja o to samo modliłem się, ale i za naszą babunię ${ }^{73}$.

Nie wszystkie analizowane książki sięgały do trudnego tematu śmierci bliskiej osoby. Tam, gdzie fakt ten został zaakcentowany, pomimo eufemistycznych opisów, zagadnienie było ujęte z należytą powagą i realizmem. Autorzy wskazywali często, że wydarzenie miało duże znaczenie duchowe, które wpłynęło na ukształtowanie się określonych cech charakteru małego Karola:

\footnotetext{
${ }^{73}$ K. Tomaszewicz, dz. cyt., s. 30-31.
} 
- Czy dlatego, że zobaczył w Maryi drugą mamę?

- Prawdopodobnie. Gdy zabrakło mu ziemskiej mamy, znalazł ukojenie i pociechę w Matce Bożej (Kalwaryjskiej) ${ }^{74}$.

Pisanie o Karolu Wojtyle zmuszało do zmierzenia się także z kilkoma trudnymi tematami, wynikającymi bezpośrednio z wybranej przez niego drogi życiowej. Istotnym elementem treści bywała konfrontacja nietypowego kapłańskiego powołania ze współczesną, hedonistyczną wizją świata:

- Teraz rozumiem, jak dojrzewało jego powołanie...

- Mylisz się. To tylko sprawiło, że stał się „bardziej dorosły”. Nie naśladował starszych, jak to zwykle robią dzieciaki, żeby pokazać, że są dorośli: papierosy, piwo, późne powroty do domu...

- Wydaje mi się, że nie był zbyt... rozrywkowy...

- I tu się mylisz: na pewno nie był „nudziarzem”. Był silnym, wysportowanym chłopcem. Kochał przyrodę i miał bogatą wyobraźnię ${ }^{75}$.

Podkreślano także wychowanie małego Karola w atmosferze tolerancji wobec różnych religii i narodowości, czego owocem były późniejsze ekumeniczne inicjatywy Jana Pawła II. Fabuły oparte na relacjonowaniu życia Karola Wojtyły nawiązywały zazwyczaj do klasycznego schematu powieści rozwojowej. Ich cechą charakterystyczną było ukazanie człowieka doskonalącego swoje życiowe umiejętności, rozszerzano tym samym zakres miejsc, wydarzeń i działań głównej postaci ${ }^{76}$. W wielu przypadkach dobór poszczególnych epizodycznych „obrazków” był dokonany ze względu na owo dojrzewanie bohatera. Dydaktyzm zmierzał do ukazania Karola Wojtyły jako osoby spełnionej, człowieka, który całym swoim życiem wypełnił plan służby Bogu i ludziom ${ }^{77}$. Bardzo często koncentrowano się także na przedstawieniu młodzieńczych zainteresowań przyszłego papieża: dotyczyło to głównie piłki nożnej, książek, teatru i krajoznawczych wycieczek. Nie zapominano przy tym o wpływie wiary katolickiej, umocnionej w trakcie okupacji niemieckiej poprzez kontakt ze sługą bożym Janem Tyranowskim ${ }^{78}$. Do młodzieńczego zauroczenia Karola Wojty-

${ }^{74}$ M. Bednarska-Moskwa, dz. cyt., s. 8.

75 T. Pagot, dz. cyt., s. 13.

${ }^{76}$ Por. B. Hadaczek, Czas i przestrzeń w konstrukcji bohatera powieści rozwojowej, „Przegląd Humanistyczny” 1981, nr 7-9, s. 117-127.

77 T. Pagot, dz. cyt., s. 9-28.

${ }^{78}$ Por. np. M. Maliński, Przyjaciel ludzi dużych i małych..., s. 38-41. 
ły „żywym słowem” nawiązywały ciekawe interwały filmowe, znajdujące się w opowieści $Z$ Piotrem nowych czasów ${ }^{79}$. Powieść stanowiła zaproszenie do tworzenia filmu, nie miała zatem charakteru jednowymiarowego, ale przez powtarzające się co rozdział dygresje zachęcała do twórczych działań pod patronatem „papieskiego aktora”. Jan Paweł II to z pewnością papież, który nadał nowy sens pielgrzymce:

Ten Papież wyczuł, że skończyły się czasy, kiedy wystarczyło siedzieć w Rzymie, w Watykanie i przyjmować tych, którzy zechcą mu złożyć wizytę. [...] Ten Papież wyczuł, że ludzie chcą gościć go w swoim kraju. Chcą mu się zwierzyć ze swoich spraw zarówno z radości, jak z kłopotów, i chcą wysłuchać Jego pasterskiego słowa ${ }^{80}$.

Ukazywanie zróżnicowanych form działania następcy św. Piotra stanowiło sposób na przybliżenie młodemu pokoleniu tej niezwykłej postaci. Uwagę zwraca próba familijnego traktowania poszczególnych księży, o czym świadczą używane wobec nich zwroty, np. Stasiu. Pomimo szeregu utworów odwołujących się do podróży Jana Pawła II wydaje się, że w tym elemencie jego biografii tkwi jeszcze znaczny potencjał, który może być wyzyskany do celów dydaktycznych. Wprawdzie Joanna Krzyżanek poświęciła „turystyce” papieża całą książeczkę ${ }^{81}$, jednak tekst ten razi niezbyt logicznym sposobem opisu tras oraz przesadnym nagromadzeniem niepotrzebnych szczegółów ${ }^{82}$.

Znacznie rzadszym schematem opowieści o Karolu Wojtyle były teksty, w których biografia papieża stanowiła wprawdzie główny temat opowieści, ale nie sytuowano go w roli pierwszoplanowego bohatera. Motyw papieski pojawia się w książce Justyny Kiliańczyk-Zięby Za rękę z papie$\dot{z} e m^{83}$ na zasadzie koincydencji, ponieważ główny bohater urodził się tego samego dnia roku co słynny wadowiczanin. W opowiadaniu Stefana Denkiewicza $Z$ Piotrem nowych czasów w realiach końca lat 70. są relacjonowane przygody chłopca z nadnarwiańskiej Ostrołęki, który mimo przeszkód natury finansowej i urzędowej postanawia „po kryjomu” od-

${ }^{79}$ S. Denkiewicz, dz. cyt., np. s. 7, 37.

80 Tamże, s. 73.

81 J. Krzyżanek, $O$ tym, jak Jan Paweł II...

${ }^{82}$ Nierzadko zresztą błędnych - jak np. informacja o największym kościele świata położonym rzekomo na Wyspach Owczych, podczas gdy wspomniane przez autorkę Yammousoukro jest miastem na terenie Wybrzeża Kości Słoniowej; tamże, s. 34.

${ }^{83}$ J. Kiliańczyk-Zięba, Za rękę z papieżem, Kraków 2004, s. 5. 
wiedzić Jana Pawła II w Rzymie. Oczywiście, tego typu fikcyjna eskapada jest doskonałą okazją do przekazania szeregu nauk moralnych oraz podkreślenia autorytetu papieża, który stanowi niejako ostatnią instancję wypowiadającą sądy na temat czynów małego pielgrzyma. Z drugiej strony, sceny z udziałem głowy Kościoła wpisują się w charakterystyczny dla Karola Wojtyły ludzki sposób sprawowania najwyższej w hierarchii kościelnej władzy, w którym rzeczy wielkie i wzniosłe są bliskie rzeczom małym, zwyczajnym i codziennym:

Bierze słuchawkę papież:

- Nie proszę pani, Stasio nie żartuje, jest u mnie, u papieża Jana Pawła II.

Matka przez łzy:

- 0 ja nieszczęśliwa. Żartuje ktoś w takiej chwili.

Głos męski w słuchawce:

- Nie żartuje. Z centrali powiedziano, że telefon jest z Watykanu.

- Tak to jestem ja, papież Jan Paweł II. Niech będzie pochwalony Jezus

Chrystus.

- Na wieki wieków. Amen - odpowiada matka - O Boże, głos podobny

do głosu papieża.

- Ten sam.

- Nic nie rozumiem, co się dzieje ${ }^{84}$.

W większości utworów traktujących o Janie Pawle II dominował żywioł dydaktyczny. Z racji specyficznego charakteru sprawowanej przez niego posługi w książkach możemy znaleźć informacje dotyczące szczegółów ubioru, liturgii i etykiety kościelnej ${ }^{85}$ oraz topografii bliskich mu miejsc w Krakowie czy Rzymie ${ }^{86}$. Postać papieża była przedstawiana jako wzorzec osobowy. Był on ukazywany wprost, poprzez opis i ocenę jego cech charakteru: odwagi, konsekwencji, wiary, siły ducha, dobroci, miłości, zrozumienia, dystansu, dowcipu i pokory, jak również pośrednio - przez odwołanie do konkretnych sytuacji, kontrast z zachowaniem innych oraz liczne analogie. $\mathrm{W}$ wielu publikacjach moralistyka stała się jednak celem samym w sobie, pouczające maksymy tworzyły wyraźne apelatywne klauzule, które niekiedy wyróżniano graficznie ${ }^{87}$. W celach

${ }^{84}$ S. Denkiewicz, dz. cyt., s. 159-160.

${ }^{85}$ Na przykład J. Krzyżanek, 0 tym, jak Jan Paweł II..., s. 26-28.

${ }^{86}$ M. Wollny, dz. cyt., s. 138-145 i 156-158.

${ }^{87}$ Na przykład D. Kuźnik, Święty jak Ojciec Święty Jan Paweł II, Częstochowa 2009. 
homiletycznych często wykorzystywano fragmenty żywych wypowiedzi papieża ${ }^{88}$. Justyna Kiliańczyk-Zięba zaproponowała nowatorski sposób przedstawienia nauk moralnych, oparty na antypedagogice ${ }^{89}$. Główny bohater jest porównywany z papieżem i chociaż z pewnością dąży do tego, aby mu dorównać, to jednak nie zawsze mu się to udaje z przyczyn jak najbardziej oczywistych:

Ostatnio dowiedzieliśmy się też, co trzeba zrobić, żeby zostać papieżem. Na początku jest dość trudno: trzeba się dobrze uczyć, chodzić do kościoła, być grzecznym i słuchać rodziców. Potem idzie się do seminarium [...]. A potem trzeba po prostu awansować na biskupa i arcybiskupa. Przedostatni stopień jest wtedy, kiedy papież mianuje wybranego biskupa kardynałem [...]. A taki kardynał, kiedy umrze papież, może być przez innych kardynałów wybrany [...]. Nie jest łatwo, ale skoro udało się już tylu papieżom, może się uda też nam. [...]. Jest tylko jeden problem. Obydwaj nie możemy być papieżem ${ }^{90}$.

\section{Podsumowanie}

Ian Paweł II dla większości Polaków jest największym bohaterem współczesnych czasów. Jego znaczenie w historii naszego narodu jest trudne do przecenienia, a charyzma, jaką był obdarzony, stanowi absolutny ewenement, szczególnie w dobie relatywizmu i braku poszanowania autorytetów. Ogromne zainteresowanie tym niezwykłym człowiekiem przekłada się także na znaczną liczbę książek poświęconych jego osobie, w tym również tych adresowanych do dzieci i młodzieży. Naturalnym zjawiskiem był wzrost liczby tego typu opracowań bezpośrednio po jego śmierci, jak też pojawianie się kolejnych pozycji przygotowanych nie tylko przez katolickie instytucje wydawnicze. Fakt ten świadczy o uniwersalności opisywanej postaci, wykraczającej daleko poza Kościół rzymskokatolicki, wpisującej się także we wzorce polskiego patrioty, człowieka aktywnego twórczo, podróżnika, poligloty. Zarejestrowane książki charakteryzował z pewnością zróżnicowany zasięg oddziaływania. Obok utworów autorstwa znanych postaci nierzadko były to przedsięwzięcia

\footnotetext{
${ }^{88}$ Por. J. Majewska, dz. cyt., s. 66-80.

89 J. Kiliańczyk-Zięba, dz. cyt.

90 Tamże, s. 24.
} 
ukazujące świadectwo żarliwej miłości i szacunku do wielkiego rodaka ze strony lokalnych społeczności. Istniejącą ofertę wydawniczą dla dzieci i młodzieży cechowało dość duże zróżnicowanie zarówno gatunków, treści, jak i sposobów widzenia papieża. W przedstawianych biografiach Jana Pawła II współistniały z reguły trzy autonomiczne tendencje: wierność faktom, przystosowanie wypowiedzi do możliwości percepcyjnych młodego odbiorcy oraz wprowadzenie elementów klasycznej hagiografii. Kierunki te należało często pogodzić w ramach jednej fabuły. Warto więc podkreślić pewną trudność $\mathrm{w}$ adaptacji papieskiej biografii dla potrzeb młodego odbiorcy. Niuanse hierarchii kościelnej, niełatwe życiowe wybory w obliczu dwóch totalitaryzmów, przy tym niewielka, z punktu widzenia nowego pokolenia, atrakcyjność tekstów homiletycznych - wszystko to wymagało szczególnego uwypuklenia niektórych tylko wątków życiorysu papieża. Z drugiej strony, większość autorów analizowanych prac postawiła sobie za cel zbudowanie tradycyjnego pozytywnego wzorca osobowego, alternatywnego wobec obecnych idoli popkultury. Wydaje się, że - zważywszy na stosunkowo dużą liczbę publikacji i szacowane względnie relatywnie wysokie ich nakłady ${ }^{91}$ (a także szereg wznowień) - sprzeczności te większość analizowanych dzieł udanie przezwyciężyła. Pomimo wielości i różnorodności wątków składających się na bogate życie Karola Wojtyły omówione książki cechują się również dużą dozą autentyzmu, który sam w sobie stanowi wartość zaświadczoną w słowach: „prawdziwe historie są właśnie najciekawsze” ${ }^{92}$.

\section{Books for children and young people on John Paul II. Analysis of the Polish publishing market Abstract}

John Paul II is widely regarded as one of the most eminent Poles in the history. This charismatic figure was a spiritual leader of the whole nation. His morals, deeds and attitude made him a role model for younger generation. Biography of the pope covers many intriguing threads that can constitute groundwork for interesting work of literature. So there was nothing strange in the fact that several dozen books about the Slavic pope for children and young people appeared on

\footnotetext{
${ }^{91}$ Przekraczające w niektórych przypadkach 100 tys. egz. Por. J. Wolak, dz. cyt., s. 26.

92 M. Bednarska-Moskwa, dz. cyt., s. 4.
} 
Polish publishing market. The article records and describes this kind of publications both from bibliological point of view - taking into account such phenomena as chronology and publishing geography, uppermost publishers, authorship or typology of the genre - and from literary point of view - pointing out versatility of approach to presentation of John Paul II biography in Polish literature for children and young people. 